\title{
INFLUENCE OF HUMAN RESOURCE MANAGEMENT ON ACADEMIC PERFORMANCE OF TRAINEES IN PUBLIC PRIMARY TEACHER TRAINING COLLEGES IN KENYA
}

\author{
Margaret Nyambura Wagithunu ${ }^{1}$, Paul Edabu' ${ }^{2 *}$, Ganatusanga Haroon Sinan ${ }^{3 *}$ \\ *1,2,3 Mount Kenya University P.O Box 324-01000 Thika, Kenya \\ *Corresponding Author:
}

\begin{abstract}
: -
Importance of human resource management on academic performance of teacher-trainees in teacher training colleges cannot be over-emphasized. However, academic performance of teacher-trainees has been dismal and continues to be on a downward trend. The purpose of this study was to investigate the influence of human resource management on academic performance of trainees in public primary teacher training colleges in Kenya. The study was guided by the human capital theory. The study adopted mixed methods approach and thus applied concurrent triangulation research design. Qualitative data were analyzed thematically along the objectives and presented in narrative forms, whereas quantitative data was analyzed descriptively and inferentially using Chi-Square test. The study established that human resource management does effectively influence teacher trainees' academic performance in public TTCs in Kenya. The study concludes that though the human resources are important, but were in adequate to influence on trainees' academic performance in public PTTCs in Kenya. Improvement on human resource management shall greatly improve trainees' academic performance in PTTCs in Kenya. The study recommends that PTTCs should have enough, adequate human resources.
\end{abstract}

Keywords: - Human Resource Management, Academic performance, teacher-trainees, public teacher training colleges

\section{(c) $(\$)$}




\section{INTRODUCTION}

Human resource plays a critical role in realization of educational objectives and to optimize staff deployment, a systemic balance must be achieved. Key to realizing it is a thorough knowledge of the quantitative and qualitative aspects of the human resource pool, of short- and medium-term staffing requirements and of the supply and demand for needed skills on the open job market. In global perspective, many governments primary teacher training colleges face competing pressures which consist of the need for tutors to register higher performance by delivering high quality services to teacher trainees and at the same time improve efficiencies and reduce costs. Ivancevich (2007) reports that performance of tutors has been a challenge in the world and particularly in the third world countries. To mitigate these challenges, successful primary teacher training colleges are increasingly realizing that there are number of practices that contribute to performance of tutors with human resource being the most critical (Mello, 2006). In a study conducted in the Netherlands, Chan and Kuok (2011) reports that human resource management practice refers to the generally accepted rules or procedures set to guide training colleges to achieve the set goals as they appear in the mission and vision of the training institutions. Chan and Kuok (2011) noted that, in today's knowledge recruitment, selection, orientation, rewards, compensation, primary teacher training colleges where value is locked in the heads of performance appraisal, training and development and the work force, best human resource management practices only can ensure labor relations. Chan and Kuok (2011) further assert that practices are the flow of information through interrelated stages of analysis towards the achievement of the set goals.

In a study conducted amongst 12 tertiary institutions in Kuala Lumpur, Boselie, Dietz and Boon (2015) agree that the most common human resource management practices comprise of training and development, pay and reward, and performance management. Boselie et al (2015) studied the impact of human resource management policies and practices on institutional performance and found that these practices have a significant impact on tutor outcome (turnover and productivity) and on overall performance. These findings affirm the fact that human resource management practices are likely to offer an array of benefits including commitment competency and flexibility, improved tutors' performance and teacher trainees' performance in PTE, mid-course examinations, CATs, RATs and teaching practice assessment. In most countries in SubSaharan Africa, the situation is not quite different where the pressing need is to ensure that an estimated 3.8 million additional teaching posts must be recruited and was to be trained by 2015 in order to realize MDGs (Ekwoaba, Ikeije \& Ufoma, 2015). Affective commitment and job satisfaction are desirable tutor behaviour outcomes that are an outcome of tutors' perception on college experiences derived from appropriate human resource management practices (Ekwoaba $e t$ $a l, 2015)$. The tutor behaviour outcomes have strongly and consistently been associated with desired work outcomes such as efficiency, profitability, productivity and low meeting deadlines among others (Ekwoaba, Ikeije and Ufoma, 2015). Human resource management scholars suggest that primary teacher training colleges can use performance and commitment oriented human resource practices to drive the desired primary teacher training college effectiveness (Ahmad \& Schroeder, 2013).

In a study conducted in Nigeria, Wright, Gardener and Moynihan (2011) argue that human resource management practices have a direct impact on tutors' knowledge, skills, motivation and behaviour which in turn influences the proximal indices of primary teacher training college performance such as operational efficiency, productivity, profitability, learning and growth. Wright et al (2011) found that any selected human resource management practices by a teacher training college work almost immediately and have desired consequences on tutors' behaviors and attitudes when tutors perceive them in the desired manner. Therefore, when quality working life initiatives are implemented effectively, they are likely to cause tutors to perceive the employer-tutor relationship as a profitable exchange hence feel obliged to develop a bond with the college which may lead to better teacher-trainees' performance. However, this has remained a challenging task for most governments. Kenya is a victim of such (Ajuoga, Indoshi \& Agak, 2010). Thus, there is all likelihood that the state of affairs can only persist, hence making the achievement of EFA by 2015 a mere wishful thinking. In regard to college tutor deployment, Ajuoga et al (2010) assert that there is need thus to address equal distribution of college tutors in sub-counties, carry out registration of all college tutors, have all untrained college tutors trained through in-service courses, put in place adequate staffing norms at all levels to make maximum use of college tutors, define the concept of a college tutor as a professional within acceptable professional principles.

In Kenya tutors employed by the Teachers Service Commission earn relatively low wages than counterparts in other professions thus lowering their morale which translates into low quality training. Trainers should employ productive practices such as teamwork and initiate enabling working environment. Teamwork may also facilitate sharing of knowledge UNESCO (2009). However, this has not been the case, it needs to be facilitated and encouraged by stakeholders particularly by the MoEST. To lend credence to these assertions, Nafukho (2002) posits that the quality of instruction is one of the most important determinants of the level of learning achievements. Despite these assertions, much still needs to be done to interrogate how human resource management practices adopted by the public primary teacher training colleges influence academic performance of teacher-trainees in Kenya. Studies conducted by Ajuoga et al (2010) as did other empirical studies have not articulated how specific college tutor and other human resource dynamics influence academic performance; hence the need for the study.

\section{Statement of the problem}

Importance of human resource management on academic performance of teacher-trainees in teacher training colleges cannot be over-emphasized. However, academic performance of teacher-trainees has been dismal and continues to be on a downward trend. As stated in the background, performance of teachertrainees in CATs, mock examinations, and teaching practice and PTE examinations is very low. Despite the concerted efforts by the Government of Kenya to provide resources to public PTTCs such as money (subsidy) to improve condition in the classrooms, libraries and library materials, lab 
equipment, textbooks and reference materials, college administrators, tutors, grant in aids, audit services and bursaries for needy students, it is not yet known how those resources are managed in relation to teacher-trainees' academic performance. It was against this background that this study sought to investigate the influence of human resource management on academic performance of teacher-trainees in public teacher training colleges in Kenya.

\section{Research Methodology}

The study applied mixed methods approach. The study used concurrent triangulation design. Questionnaires were used to collect data from college tutors and teacher-trainees, interview guide from principals and the deans of curriculum. Data analysis began by identifying common themes from the respondents' description of their experiences. Qualitative data was analyzed thematically along the study objectives and presented in narrative forms whereas the quantitative data was analyzed using descriptive statistics and inferentially using Chi-Square Analysis with the help of Statistical Package for Social Science (SPSS 23) and presented using tables and charts.

\section{Results and Discussions}

Human Resource Management and Academic Performance of Trainees in Primary Teacher Training Colleges The study sought to find out the influence of human resource management on academic performance of teacher-trainees in public primary teacher-training colleges. Descriptive data was collected from college tutors and teacher-trainees, organized into specific thoughts and results are indicated in Table 1;

Table 1: Views of College Tutors and Teacher-Trainees on the Influence of Human Resource Management on Academic Performance of Trainees in PTTCs

\begin{tabular}{|c|c|c|c|c|c|c|}
\hline Test Items & RESP & Rati & & & & \\
\hline & & $\mathbf{S A}$ & $\mathbf{A}$ & $\mathbf{U}$ & D & SD \\
\hline & & $\%$ & $\%$ & $\%$ & $\%$ & $\%$ \\
\hline Tutors are not well remunerated to improve trainees' & CT & 80.5 & 8.5 & 1.5 & 5.5 & 4.0 \\
\hline performance & TT & 88.3 & 5.4 & 1.9 & 2.3 & 2.1 \\
\hline Public TTCs do not frequently promote tutors as a & CT & 78.5 & 14.5 & 2.5 & 3.0 & 1.5 \\
\hline $\begin{array}{l}\text { way of making trainees perform well in mocks and } \\
\text { PTE }\end{array}$ & TT & 77.2 & 13.3 & 1.5 & 6.3 & 1.7 \\
\hline Trainees do not have sufficient time to discuss their & CT & 69.5 & 12.0 & 2.0 & 10.0 & 6.5 \\
\hline $\begin{array}{l}\text { problems which has affected their academic } \\
\text { performance }\end{array}$ & TT & 75.3 & 20.1 & 1.4 & 1.3 & 1.9 \\
\hline The tutors have the capacity to train PI teachers & CT & 74.5 & 17.0 & 2.5 & 3.5 & 2.5 \\
\hline effectively in training colleges & TT & 59.9 & 27.4 & 3.3 & 5.7 & 3.7 \\
\hline Many tutors do not frequently undergo proficiency & CT & 67.0 & 11.5 & 5.5 & 8.5 & 7.0 \\
\hline $\begin{array}{l}\text { training to enhance trainees' performance in } \\
\text { examinations }\end{array}$ & TT & 76.0 & 18.1 & 1.7 & 2.7 & 3.5 \\
\hline All tutors are not competent in training of trainees to & CT & 75.0 & 10.5 & 2.5 & 9.0 & 3.5 \\
\hline enhance performance & TT & 62.5 & 19.8 & 2.8 & 10.2 & 4.7 \\
\hline Scholarships and performance appraisal offered to & CT & 88.5 & 2.5 & 1.5 & 4.5 & 3.0 \\
\hline tutors has not improved trainees' performance & TT & 62.5 & 9.9 & 3.7 & 13.7 & 10.2 \\
\hline
\end{tabular}

Key: RESP-Respondents; CT-College Tutors; TT-Teacher-Trainees Source: Researcher (2017)

Table 1 reveals that $126(80.5 \%)$ CT and $170(88.3 \% \mathrm{TT})$ strongly agreed with the view that tutors are not well remunerated as a way of improving teaching process for impressive trainees' performance in mocks, mid-course and PTE examinations as did $14(8.5 \%) \mathrm{CT}$ and $11(5.4 \%)$ TT who agreed. However, only a paltry $3(1.5 \%)$ of the college tutors as well as $4(1.9 \%)$ of teacher-trainees were undecided, $9(5.5 \%)$ of college tutors as did $5(2.3 \%)$ of the teacher-trainees disagreed whereas $4(4.0 \%)$ of college tutors and $4(2.1 \%)$ of the teacher-trainees strongly disagreed. These findings are consistent with the findings of a study conducted in Pakistan in which Mahmood (2010) noted that those responsible for the management of human resources have a responsibility to establish and maintain a work-place environment that is conducive to achieving academic performance. Concretely, that entails recognizing and handling staff claims the nature of which is expanded from salaries and working conditions to include promotion and career questions (Mahmood, 2010).

These findings also support the assertions of GMR (2006) that many countries face a crisis of college tutor morale that is mostly related to poor salaries, working conditions and limited opportunities for professional development. Other problems include the doubtful use of contract college tutors and the lack of evidence for introducing performance related pay structures. This implies that tutor empowerment is also believed to be a motivator since tutor involvement in decisionmaking makes them feel valued. In an effort to assume their responsibilities more effectively, Education Ministries are adopting a more pro-active stance by involving college tutor union representatives in the identification of potential areas of conflict and areas of compromise, taking into account budgetary and policy-linked constraints. The study also found out that majority of the respondents $(78.5 \% \mathrm{CT}$ and $77.2 \% \mathrm{TT})$ strongly agreed with the view that public TTCs do not 
frequently promote tutors as a way of motivating them to ensure that trainees work hard and perform well in mocks and PTE.

At the same time, $14.5 \%$ of the college tutors as did $13.3 \%$ of the sampled teacher-trainees agreed. However, $2.5 \%$ of college tutors and $1.5 \%$ of the teacher-trainees were undecided, $3.0 \%$ of college tutors and $6.3 \%$ of the teacher-trainees disagreed whereas $1.5 \%$ of the teacher-trainees as did $1.7 \%$ of the teachertrainees strongly disagreed. These findings lend credence to the findings of a study conducted by Shindler (2010) who revealed that management of the personnel is an extension of general management that is concerned with promoting and stimulating every employee to make his fullest contribution for the purpose of the organization.

These findings also support the assertions of Olembo et al (1992) who noted that teacher management is a critical government issue that is concerned with ensuring there are adequate teachers in classrooms, sustaining these teachers and continuing to expand the teaching force to meet the growing demand for education. The study also revealed that majority of the respondents $(69.5 \% \mathrm{CT}$ and $75.3 \% \mathrm{TT})$ strongly agreed with the view that trainees do not have sufficient time to discuss their problems with tutors and has thus negatively affected their academic performance. On the same breath, $12.0 \%$ of the college tutors as did $20.1 \%$ of the sampled teacher-trainees agreed. However, $2.0 \%$ of college tutors and $1.4 \%$ of the teacher-trainees were undecided, $10.0 \%$ of college tutors and $1.3 \%$ of the teacher-trainees disagreed whereas $6.5 \%$ of the college tutors as did $1.9 \%$ of the teacher-trainees strongly disagreed.

These findings are consistent with the assertions of Mahmood (2010) that, in an effort to assume their responsibilities more effectively, Education Ministries are adopting a more pro-active stance by involving college tutor union representatives in the identification of potential areas of conflict and areas of compromise, taking into account budgetary and policy-linked constraints. The unions themselves are evolving to the extent that they too are participating in human resource development programmes (Mahmood, 2010). Mahmood (2010) further notes that planning work and overseeing working conditions are two major concerns of human resource managers. Majority of the respondents $(74.5 \% \mathrm{CT}$ and $59.9 \% \mathrm{TT}$ ) strongly agreed with the view that the tutors have the capacity to train PI teachers effectively in training colleges. $17.0 \%$ of the college tutors and $27.4 \%$ of the teacher-trainees agreed.

At the same time, $2.5 \%$ of the sampled college tutors and $3.3 \%$ of teacher-trainees were undecided, $3.5 \%$ of college tutors and $5.7 \%$ of the teacher-trainees disagreed whereas $2.5 \%$ of the college tutors as did $3.7 \%$ of the teacher-trainees strongly disagreed. On the same breath, majority of the respondents (67.0\% CT and 76.0\% TR) strongly agreed with the view that many tutors do not frequently undergo proficiency training to acquire new strategies to enhance trainees' academic performance in mid-course, mocks and PTE examinations. $11.5 \%$ of the college tutors and $18.1 \%$ of the teacher-trainees agreed. At the same time, $5.5 \%$ of the sampled college tutors and $1.7 \%$ of teacher-trainees were undecided, $8.5 \%$ of college tutors and $2.7 \%$ of the teacher-trainees disagreed whereas $7.0 \%$ of the sampled college tutors as did $3.5 \%$ of the teachertrainees strongly disagreed.

These findings lend credence to the assertions of UNESCO (2008) that, as a contribution to the academic performance of primary teacher training colleges, it has contributed to national capacity-building in the development and use of models that simulate educational policies and strategies. These findings are also consistent with the findings of a study conducted by Saleem (2010) who identifies different managerial challenges related to human resource management. These are like recruitment of employees, orientation and induction of the newly employed workers, training and development of workers, motivational challenges, compensation and appraisal of workers. Saleem (2010) did a study on business world identifying challenges facing managers in human resource management. Hence, these findings affirm the fact that, to attain sound academic achievements in both internal and national examinations, human resource training and upgrading the quality of teaching is the point of entry for education sector renewal strategy. It presupposes that, because no pre-service college tutor or staff training programme, however good it may be, is sufficient by itself to prepare college tutors for their entire career, continuous upgrading is necessary.

Majority of the respondents (75.0\% CT and 62.5\% TT) strongly agreed with the view that all the tutors are not competent in their training of trainee teachers and has negatively affected trainees' academic performance. $10.5 \%$ of the sampled college tutors and $19.8 \%$ of the sampled teacher-trainees agreed. At the same time, $2.5 \%$ of the sampled college tutors and $2.8 \%$ of teacher-trainees were undecided, $9.0 \%$ of college tutors and $10.2 \%$ of the teacher-trainees disagreed whereas $3.5 \%$ of the sampled college tutors as did $4.7 \%$ of the teacher-trainees strongly disagreed. These findings corroborate the findings of a study conducted in Mexico in which Rivkin, Eric and Hanushek (2008 observed that, to attain sound academic achievements in both internal and national examinations, human resource training and upgrading the quality of teaching is the point of entry for education sector renewal strategy. Rivkin et al (2005) further noted that, in-service training, however, while arguably a powerful tool to raise competency levels and keep college tutors abreast of new trends in educational goals, occupies at best a modest place in Education Ministry programmes.

Majority of the respondents $(88.5 \% \mathrm{CT}$ and $62.5 \% \mathrm{TT})$ strongly agreed with the view that scholarships offered to tutors are not sufficient to promote trainees' academic performance. A paltry $2.5 \%$ of the sampled college tutors and $9.9 \%$ of the sampled teacher-trainees agreed. At the same time, $1.5 \%$ of the sampled college tutors and $3.7 \%$ of teacher-trainees were undecided, $4.5 \%$ of college tutors and $13.7 \%$ of the teacher-trainees disagreed whereas $3.0 \%$ of the college tutors as did $10.2 \%$ of the teacher-trainees strongly disagreed. These findings also lend credence to the assertions of Mohanty (2010) that pre-service training typically targets the learning of the various subject matters and generally neglects the pedagogical and practical aspects of teaching in primary teacher training colleges. To the extent that it fails to incorporate the specificity of difficult urban and rural contexts, it may indeed be completely cut off from field realities (Mohanty, 2010). In other words, unrelated to in-service training possibilities, it is not part and parcel of a global vision of college tutor preparation and support. Thus, these findings affirm the fact that on-going education in the developing countries is a work in progress since neither the means nor the ends have been clarified in any operational way. In the absence of a 
clear conceptual framework for the teaching profession or any clear notion of a career, the absence of any linkage between human resource training programmes complicates the task of defining both content and delivery systems and of programming them in a manner that reaches college tutors throughout their careers. This call for a reexamination of academic performance of primary teacher-trainees in the context of a global vision taking into account the twin dimensions of skill-building namely pre- and in-service training.

Majority of the respondents $(70.0 \% \mathrm{CT}$ and $65.0 \% \mathrm{TT})$ strongly agreed with the view that performance appraisal for tutors have not been effective in enhancing academic performance in mod-course, mocks and PTE examinations. $10.0 \%$ of the college tutors and $22.1 \%$ of the sampled teacher-trainees agreed. At the same time, $3.5 \%$ of the sampled college tutors and $3.5 \%$ of teacher-trainees were undecided, $14.5 \%$ of college tutors and $3.7 \%$ of the teacher-trainees disagreed whereas $12.0 \%$ of the sampled college tutors as did $4.5 \%$ of the teacher-trainees strongly disagreed. These findings corroborate the assertions of Marzano, Marzano and Pickering (2011) that college tutors are not governed by the same rules that apply to their non-teaching colleagues. The weekly workload is variable since it depends on the particulars of the specific teaching situation. Staff motivation and work output correlate closely to how time is managed, to the primary teacher training college environment and to the quality and timeliness of administrative, instructional and personal support. As regards college tutor workload management, several options are available. This point to the fact that tutor behavior outcomes have strongly and consistently been associated with desired work outcomes such as efficiency, profitability, productivity and low meeting deadlines among others.

Inferential Findings on the Influence of Human Resource Management on Academic Performance of Trainees in Primary Teacher Training Colleges

To verify the possibility of relationship between human resource management and trainees' academic performance in PTTCs, data was collected on the number of tutors and trainees' academic performance in PTE examinations from 2011 2015 and results are shown in Table 2:

Table 2: Results of the Number of Tutors in PTTCs and Teacher-Trainees' Performance in PTE Examinations from 2011-2015

\begin{tabular}{ll}
\hline Number of Tutors in PTTCs & Average PTE Results in Points From 2011-1015 \\
\hline 1 & 33 \\
59 & 36 \\
67 & 65 \\
74 & 71 \\
\hline
\end{tabular}

Source: Researcher (2017)

Table 2 indicates that public primary teacher training colleges which have more tutors have had manpower advantage over other teacher training colleges with few tutors. Such training colleges have had their trainees perform better in national PTE examinations. These findings are also consistent with the findings of Saleem (2010) who identifies different managerial challenges related to human resource management. These are like recruitment of employees, orientation and induction of the newly employed workers, training and development of workers, motivational challenges, compensation and appraisal of workers. These results were subjected to Chi-Square $\left(\chi^{2}\right)$ Test Analysis and results were as indicated in Table 3:

Table 3: Chi-Square $\left(\chi^{2}\right)$ Analysis Showing Relationship between the Number of College Tutors and TeacherTrainees' Performance in PTE Results

\begin{tabular}{|c|c|c|c|c|c|c|c|c|c|}
\hline & \multirow[t]{5}{*}{ Value } & \multirow[t]{5}{*}{ df } & \multirow{6}{*}{$\begin{array}{l}\text { Asym } \\
\text { Sig. } \\
(2- \\
\text { sided) }\end{array}$} & \multicolumn{3}{|c|}{$\begin{array}{l}\text { Monte Carlo Sig. (2- } \\
\text { sided) }\end{array}$} & \multicolumn{3}{|c|}{$\begin{array}{l}\text { Monte Carlo Sig. (1- } \\
\text { sided) }\end{array}$} \\
\hline & & & & Sig. & $\begin{array}{l}95 \% \\
\text { Confide } \\
\text { Interval }\end{array}$ & Ice & Sig. & $\begin{array}{l}95 \% \\
\text { Confic } \\
\text { Interva }\end{array}$ & nce \\
\hline & & & & & Lower & Upp & & Lowe & Upp \\
\hline & & & & & Bound & er & & & er \\
\hline & & & & & & Bou & & Boun & Bou \\
\hline & $12.000^{\mathrm{a}}$ & 9 & & $1.000^{\mathrm{b}}$ & 1.000 & $\begin{array}{l}\text { nd } \\
1.00\end{array}$ & & & \\
\hline Chi-Square & & & & & & 0 & & & \\
\hline Likelihood & 11.090 & 9 & 0.270 & $1.000^{\mathrm{b}}$ & 1.000 & 1.00 & & & \\
\hline Ratio & & & & & & 0 & & & \\
\hline Fisher's & 10.610 & & & $1.000^{\mathrm{b}}$ & 1.000 & 1.00 & & & \\
\hline Exact Test & & & & & & 0 & & & \\
\hline Linear-by- & $2.693^{\mathrm{c}}$ & 1 & 0.101 & $.084^{b}$ & 0.079 & 0.09 & $0.041^{b}$ & 0.037 & 0.04 \\
\hline Linear & & & & & & 0 & & & 5 \\
\hline Association & & & & & & & & & \\
\hline $\mathrm{N}$ of Valid & 4 & & & & & & & & \\
\hline
\end{tabular}

Source: SPSS Generated (2017) 
From the Chi-Square $\left(\chi^{2}\right)$ Statistics in Table 3, the processed data, generated a significance level of $0.041^{\mathrm{b}}$ which shows that the data is ideal for making a conclusion on the population's parameter as the value of significance $\left(\mathrm{p}\right.$-value of $\left.0.041^{\mathrm{b}}\right)$ is less than $5 \%$, that is, $p$-value $=0.041^{\mathrm{b}}<0.05$. It also indicates that the results were statistically significant and that there is significant relationship between number of tutors in PTTCs and teacher-trainees' academic performance in PTE examinations. These results were consistent with the findings of a study conducted by Ajuoga et al (2010) which generated a p-value of $0.025<0.05$. Just like descriptive findings above, these findings attest to the fact that the quality of instruction is one of the most important determinants of the level of learning achievements. Quality teacher training impact on the quality of teaching and learning institutions. This involves transfer of skills, knowledge, behaviour and attitudes in order to be competent employees, hence training is a must. These findings point to the fact that human resource management practices adopted by the public primary teacher training colleges influence academic performance of teacher-trainees in Kenya.

\section{Thematic Analysis of Qualitative Findings on the Influence of Human Resource Management on Academic Performance of Trainees in Primary Teacher Training Colleges}

During interviews, the principals and deans of curriculum echoed similar sentiments. The interviewees also responded in favor of the view that tutors are not well remunerated as a way of improving teaching process for impressive trainees' performance in mocks, mid-course and PTE examinations. Principal, P6, as did dean of curriculum DOC6, observed,

"Many tutors are not properly numerated. Some earn very little wages to take care of their personal needs and those of their families. Many of them usually borrow money from accounts' offices and always live on edge of their earnings.

Those employed by the college on contract terms find it difficult to make ends meet. This has really affected their motivation to deliver in their class work and, in turn, lowers the academic performance of their trainees".

Just like quantitative findings, these views further corroborate the assertions of Mahmood (2010) that those responsible for the management of human resources have a responsibility to establish and maintain a workplace environment that is conducive to achieving academic performance. This entails recognizing and handling staff claims the nature of which is expanded from salaries and working conditions to include promotion and career questions (Mahmood, 2010). These views affirm the fact that many countries face a crisis of college tutor morale that is mostly related to poor salaries, working conditions and limited opportunities for professional development. Other problems include the doubtful use of contract college tutors and the lack of evidence for introducing performance related pay structures.

That is, tutor empowerment is also believed to be a motivator since tutor involvement in decision-making makes them feel valued. However, the principals disagreed with the view that public TTCs do not frequently promote tutors as a way of motivating them to ensure that trainees work hard and perform well in mocks and PTE. Principals, P7, noted,

"Many of our tutors are promoted based on the regulations from the Ministry of Education and thus any tutor eligible for promotion is often accorded the privilege".

These views were echoed by deans of curriculum who equally observed that tutors are often promoted based on Ministry guidelines. Just like in quantitative findings, these views lend credence to the viewpoints held by Shindler (2010) who noted that management of the personnel is an extension of general management that is concerned with promoting and stimulating every employee to make his fullest contribution for the purpose of the organization. This further affirms the fact that teacher management is a critical government issue that is concerned with ensuring there are adequate teachers in classrooms, sustaining these teachers and continuing to expand the teaching force to meet the growing demand for education. The interviewees also agreed with the view that trainees do not have sufficient time to discuss their problems with tutors and has thus negatively affected their academic performance. Principal, P7, noted,

"Due to busy schedule, most of the tutors do frequently have time to discuss problems affecting trainees. Time table for teaching is congested and sometimes it becomes difficult to spare time to help trainees with their personal challenges. This has affected their performance in mocks, midcourse and PTE examinations".

These views also support the views expressed by Mahmood (2010) that, in an effort to assume their responsibilities more effectively, Education Ministries are adopting a more pro-active stance by involving college tutor union representatives in the identification of potential areas of conflict and areas of compromise, taking into account budgetary and policylinked constraints. The interviewees also concurred with the view that the unions themselves are evolving to the extent that they too are participating in human resource development programmes.

This implies that planning work and overseeing working conditions are two major concerns of human resource managers. However, the principals and deans of curriculum responded in favor of the view that tutors have the capacity to train PI teachers effectively in training colleges. On further probing, principal, P8, and dean of curriculum, noted, 
"Our college tutors have the capacity to be teacher trainers since they have right qualifications, plausible experience and mastery of content. In fact, all the tutors are bachelors' degree holders whereas others possess postgraduate qualifications".

These views thus support the views expressed by UNESCO (2008) that, as a contribution to the academic performance of primary teacher training colleges, it has contributed to national capacity-building in the development and use of models that simulate educational policies and strategies. The interviewees also concurred with the viewpoints of Saleem (2010) who identified different managerial challenges related to human resource management. These are like recruitment of employees, orientation and induction of the newly employed workers, training and development of workers, motivational challenges, compensation and appraisal of workers. These views thus attest to the fact that, to attain sound academic achievements in both internal and national examinations, human resource training and upgrading the quality of teaching is the point of entry for education sector renewal strategy.

The interviewees also concurred with the fact that to attain sound academic achievements in both internal and national examinations, human resource training and upgrading the quality of teaching is the point of entry for education sector renewal strategy. Human resource management aspects such as in-service training, however, while arguably a powerful tool to raise competency levels and keep college tutors abreast of new trends in educational goals, occupies at best a modest place in Education Ministry programmes. To achieve this, tutor motivation and work output correlate closely to how time is managed, to the primary teacher training college environment and to the quality and timeliness of administrative, instructional and personal support. As regards college tutor workload management, several options are available. In other words, tutor behavior outcomes have strongly and consistently been associated with desired work outcomes such as efficiency, profitability, productivity and low meeting deadlines among others.

\section{Summary of Findings}

From the study findings, it is evident that human resource management influences academic performance of teachertrainees as research gap. The study established that many college tutors are not well remunerated as a way of improving teaching process for impressive trainees' performance in mocks, midcourse and PTE examinations. These findings affirm the fact that the management of human resources should establish and maintain a work-place environment that is conducive to achieving academic performance. The study also established that public TTCs do not frequently promote tutors as a way of motivating them to ensure that trainees work hard and perform well in mocks and PTE. To attain sound academic achievements in both internal and national examinations, human resource training and upgrading the quality of teaching is the point of entry for education sector renewal strategy.

\section{Conclusion and Recommendation}

From the study findings, it is conclusive that human resource management facilities were in adequate to influence teacher trainees' academic performance in public TTCs in Kenya. The study further concludes that human resource facilities ranging from personnel to services offered was in adequate to influence teacher trainees' academic performance in public TTCs in Kenya. The study also concluded that teacher trainees were not adequately provided with appropriate human resources in order to equip them with necessary skills. The study thus recommends that PTTCs should have enough, adequate human resource management facilities to influence teacher trainees' academic performance in public TTCs in Kenya. The TTCs should facilitate training of qualified teachers, recruiting qualified tutors and other administrators in college, have refresher courses for all the staff in the colleges to equip them with necessary skills.

\section{References}

[1].Ahmad, S. \& Schroeder, R. G. (2013). The Importance of Recruitment and Selection Process for Sustainability of total quality management, International Journal of Quality \& Reliability Management, Vol. 19 No. 5, pp. 540 - 50.

[2].Boselie, P. Dietz, G. \& Boon, C. (2015). Commonalities and Contradictions in HRM and Performance Research. Human Resource Management Journal, 15 pp 67-94

[3].Chan, S. \& Kuok, O. (2011). A study of human resources recruitment, selection, and retention issues in the hospitality and tourism industry in Macau. Journal of Human Resources in Hospitality \& Tourism, 10(4), 421-441.

[4].Creswell, J. (2009). Research design: qualitative, quantitative and mixed methods approach. Thousand Oaks, California: Sage Publications.

[5].Ekwoaba, J. O., Ikeije, U. U., \& Ufoma, N. (2015). The impact of recruitment and selection criteria on organizational performance. Global Journal of Human Resource Management, 3(2), 22-23.

[6].Ivancevich, J. M., (2007). Human Resource Management 10th Edition, McGraw-Hill Publishing

[7].Mello, K., (2006). Achieving Competitive Advantage through Human Resource Strategy: Towards a Theory of Industry Dynamics. Human Resource Management Review, 8(3), 25-38

[8].Nafukho, M. (2002). Determining optimal class size and Existence of Economies of Scale in Kakamega District Secondary Schools. Unpublished M. Ed. Thesis, Kenyatta University, Kenya.

[9].Schuler, R. S., \& Jackson, S. E. (2012). Human Resource Management: Positioning for the 21 St century, (6th Ed.), New York: West Publication Company.

[10]. Schultz, T. (1962). Investment in human capital. AER, 51: 1-17.

[11]. UNESCO, (2009). Challenges of implementing free day secondary education in Kenya. Experiences from district. Nairobi: UNESCO. 
Journal of Advance Research in Education \& Litrature (ISSN: 2208-2441)

[12]. Wright, P., Gardener, T. \& Moynihan, L. (2011). The Impact of HR practices on the performance of business units'. Human Resource Management Journal 13:3 21-36 